\title{
Political Economy of the World-System: The Imperative of African-Centered Utopias
}

\author{
Rose M. Brewer, Ph.D. \\ University of Minnesota \\ Brewe001@umn.edu
}

What is clear to me in this current moment of capitalist crisis and the demand for its alternative is this: African peoples throughout Africa and the diaspora - the United States, Brazil, the Caribbean, Europe - are at the center of dispossession: social, economic, political, and environmental. It is the continent of Africa in the context of neoimperialism and neocolonialism that closely aligns with Professor Salleh's assertion in this Symposium:

As always, the extraction of labor and resources from the margins of capitalism relies on the cooperation of compradors, groomed with incentives by the colonizer.

This is not simply an expression of the economic crisis of the world-system but multiple crises of persistent racism, imperialism, neocolonialism, environmental degradation, economic exploitation and patriarchal expropriation.

The World Capitalist System enshrines a property rights regime within nation-states in a way that guarantees the taking of dispossession off the table in discourse and practice. It uses the intersecting forces of structural racism (or the white supremacy system), patriarchy, corecapitalist-dependent nationalist projects, and a dynamic mix of national and international policies to create and sustain an increasingly unequal world (Grant and Brewer 2010).

Relatedly, as Lisa Duggan (2003) argues, the deep interpenetration of ideologies of white supremacy, sexism, and classism into neoliberal transnational capitalism cannot be ignored. This interpenetration brings the African continent in deep interconnectivity to the Black population in the United States - centered in the "heart of the beast" - as well as other parts of the African diaspora in South America, Europe, and Asia. Thus, I contend that the systems of neoimperialism and internal neocolonialism are intertwined. And it is through the ideologies of white supremacy and so-called Black incapacity (two sides of the same coin) that the system maneuvers and justifies widespread Black dispossession throughout the African World. Regarding $21^{\text {st }}$ century neoliberalism in the United States, Duggan (2003) notes:

Welfare reform and the law and order politics of the past two decades clearly illustrate the dense interrelations among neoliberalism's economic vision and its cultural projects. The goal of raising corporate profits has never been pursued separately from the rearticulation of hierarchies of race, gender, and sexuality in the United States and around the globe... They [neoliberal capitalists] make use of identity politics to obscure redistributive aims, and they use "neutral" economic policy terms to hide their investments in identity-based hierarchies... (14-15, emphasis added). 
In short, racism and other 'isms' are deeply rooted in a global, technologically-driven capitalist world order where the wealth and resources of the globe are held by a small elite of multinational firms and their comprador allies (as noted by Salleh). Moreover, there is an ideological structure in place which is intertwined with global capital. While the global owners are nearly all nonAfrican males, the comprador allies are, and they benefit richly from the current arrangement. At the core of world-systems analysis is an articulation of how capitalism has engendered underdevelopment in peripheries of the world consistently since 1789 through core-dominated techniques of enfolding the periphery in the world capitalist system according to the interests of the core (Wallerstein 1974).

For the poorest Black people in advanced Western capitalist societies such as the United States, the dismantling of the social wage through destruction of social welfare, attacks on public education, the increasing incarceration and imprisonment of Black men (and women), and the structural consequences of wealth concentration in the hands of a tiny elite are part and parcel of the global politics of accumulation through austerity and uneven development. A brief analysis of Hurricane Katrina is illustrative.

\section{Hurricane Katrina}

By the time of the first United States Social Forum in 2007 in Atlanta, Georgia, the Gulf coast hurricanes of Rita and Katrina had already wrought irreparable devastation. The shorthand discursive applied to the region centered on the devastation of the Black and the poor in New Orleans, Louisiana: Hurricane Katrina. Yet a deeper look reveals the whole region as the victim of the "unnatural disaster" (Dyson 2006) of deeply institutionalized poverty and racism for generations. The hardest hit regions in the Gulf states were already drowning in extreme immiseration before Hurricanes Katrina and Rita hit. Mississippi remains the poorest state in the nation, with Louisiana just behind it. More than 90,000 people, disproportionately Black, in each of the areas stormed by Katrina in Louisiana, Mississippi, and Alabama made less than \$10,000 a year in 2006 (Dyson). This is far below anything denoted as an official poverty line for a family of four in the United States, even in 2006.

This region is also the site of horrendous environmental racism: toxin dumping, pollution, and degradation. Cancer alleys, asthma epidemics, and lung diseases are prevalent throughout the southern Black belt (Bullard 1990). Sadly, the situation has not been remediated since Bullard first published his research over 20 years ago. The capitalist, commodified green economy will not resolve this deeply rooted environmental racism. It will intensify it.

In a connected way on the continent of Africa, the issues of environmental devastation loom large. Water privatization and desertification are at the center of the crises (Global Ecology Project). The result is the intensification of conflict catalyzed by changes in land and herding dynamics resulting from climate change. In Kenya, at the 2007 Africa-based World Social Forum, analysts stressed how water privatization had exacerbated the continent's dispossession. As Professor Mugaubi asserted at the forum, "it is a crime to deny people water because it is life." WSF discourses clearly cast these policies as rooted in the relentless search for profit and insist that profit is not life. 


\section{What's To Be Done?: African-Centered Utopias Rooted in Concrete Social Transformation}

Understanding the inequality of African diaspora peoples within the political economy of the world capitalist system demands an alternative to the current order, a new vision and practice. Dismantling neoimperialism and neocolonialism must be front and center in Africa's and African America's vision. Centrally this means that imperialism, as a logic and practice which expropriates the resources of the world and shifts these resources - land, labor, mineral, etc. into the coffers of a small elite of multinationals, must end. Concurrently, this means that neocolonialism expressed in the form of the comprador group integrated into the logic of transnational capital to the benefit of themselves and the multinationals must cease to exist.

While Africa and the African diaspora continue to live out the legacies of colonialism, neocolonialism, neoimperialism, and the multiple crises of the world capitalist system, organizing is happening in the African world and "Freedom Dreams" are in the making.

A case in point is the theory and practice of change concretized in the political vision of grassroots Brazilian group, CEAFRO. It is a community-based organization with an extension program located at the Federal University of Bahia. CEAFRO's struggle is to help craft a future for youth, and the women of CEAFRO express a powerful Black feminist consciousness. They exemplify in their work the growing and expanding awareness of how gender and race are intertwined, affecting Brazilian men and women. They are keenly intent on mobilizing the AfroBrazilian women who are locked in domestic work (empregadas) today, and Black women make up the majority of these domestics in Brazil. Many of these women are, in fact, girls. Indeed, we are talking about girls as young as 12 and 13 years old who are exploited materially, sexually, and physically. The work of CEFRO in Bahia uses a women-centered/Black feminist consciousness to make public and organize around this race, class, and gender exploitation. This kind of consciousness and practical work centered on building Black women's resistance to labor exploitation must be a recognized force in motion in the African world. I believe this work should be front and center of a World Social Forum process which pays too little attention to the experience of exploitation by the women of Africa and the African diaspora (Brewer 2008). The work of CEAFRO connects (or should connect) to the Domestic Workers Alliance, which emerged out of the 2007 USSF in Atlanta and now has international allies. Converging global resistance is imperative.

CEAFRO understands how racism shapes sexism and how sexism is shaped by class and race. This holds true in Brazil, the United States, and throughout the African diaspora. At the center of the capitalist world-system are highly exploited women whose labor is multifaceted, centered in public labor, domestic reproductive work, and unpaid home labor that goes unnamed.

Other movements worth mentioning with significance implications for the African world are The Landless Peoples Movement of South Africa and the MST movement in Brazil. They are connecting their work to the Take Back the Land movement in the United States. In turn, the United States-based movement draws upon the theory and practice of The Landless Peoples Movement of South Africa and the MST movement in Brazil.

Nonetheless, connecting to the current expressions of political change by peoples of Africa and the African diaspora to the Occupy Wall Street or the World Social Forum process will be demanding. The World Social Forum in its current expression does not reach deep enough into the dispossession of the African world. As Joyce Mulama points out in her 2007 article on the World Social Forum in Kenya, "What is WSF? Something that Will Bring Me 
Medicine?" the criticism of the Forum in Kenya by the poorest slum dwellers was sharp and pointed. One respondent said this about the Kenyan WSF:

Communities are not (so) naïve that they cannot talk about their problems. They know where they are hurting and how they want their plight addressed. Can NGOs stop using problems of poor people to enrich themselves? Can we see communities being given a chance to express themselves at meetings such as the WSF? (Mulama 2007)

Essentially, the charge for the African world involves the highly demanding work of movement building. This entails connecting the forces in motion committed to social transformation of the world capitalist system and its imperialistic face. As Sam Grant (Grant and Brewer 2010) asserts, "the people ask the question: what is to be done?" He summarizes the possibilities emerging from Africa and the African diaspora: African Nationalists propose the rights of states and a strengthening of sovereignty over natural resources, labor, monetary policy, and the environment within their borders. Internationalist-Anti-Corporate Globalization movements propose a dismantling of the corporate-dominated world political economic pact that ushers in rapid privatization and liberalization. Poor peoples' movements, whether urban or rural, make claims alternately on local authorities, the state and on global intermediaries to resist further dispossession and assert their rights to survival. A smaller, yet growing number, such as the Landless Peoples' Movement of South Africa, call for a more thorough-going transformation. In addition, there is an important and growing group of the adherents to the world-systems frame calling for organizing to build another world (Grant and Brewer 2010).

The World Social Forum process may be the gateway to the interconnected struggles so desperately needed. Professor Salleh gestures toward this possibility in her assertion that the World Social Forum is on the verge of such unification. More precisely, she notes "sociologists may not recognize this class, but the World Social Forum is coming close to unifying women's, indigenous, and ecological voices alongside the traditional proletariat." Perhaps. But my sense is that much work remains to be done. While our movements must act to end to this highly unequal world capitalist system, my concern remains the one I voiced in my overall reflection: How must the African world struggle? It certainly requires more of the WSF and the USSF to recognize white supremacy as deeply imbricated in gender, race, and class. Thus the dilemmas remain: How does a radical collectivity cohere given this history? What is the vision of social transformation given this reality?

While difficult, this stark moment of dispossession and travesty requires us to lead with complex theorizing and practice (Brewer 2008). This is the change that must occur for another world to be realized.

Indeed, transforming transnational, heteropatriarchal, white supremacist, neoliberal capitalism must be at the center of our theory and practice. This is the profound and imperative lesson of revolutionary struggles all over the world, as noted in the Greek case of the Karides essay. In movements for social transformation we simply cannot be race, gender, or class reductionist, but rather we need to employ a critically mediated understanding of these deep interrelationalities. This is the crucial lesson that the social forum process is still trying to perfect. This is our unfinished utopian call. 


\section{References}

Brewer, Rose M. 2008. "Just Between Us: Women in Struggle in Africa and the African Diaspora." In Solidarity Economy: Building Alternatives for People and Planet, edited by Jeanna Allard, Carl Davidson and Julie Matthaei. Chicago: ChangeMaker Publications.

Bullard, Robert. 1990. Race, Class and Environmental Quality. Boulder: Westview Press.

Dyson, Michael Eric. 2006. Come Hell or High Water: Hurricane Katrina and the Color of Disaster. New York: Basic Civitas.

Duggan, Lisa. 2003. The Twilight of Equality: Neoliberalism, Cultural Politics, and the Attack on Democracy. Boston: Beacon Press.

Grant, Sam and Rose M. Brewer. 2010. "Contextualizing the 21st Century Organizing Theory and Practice of African Liberation and Land Struggles in the Light of the Evolution of the Capitalist World-System." Unpublished paper presented at the Political Economy of the World Systems conference. Boca Raton, Florida.

Wallerstein, Immanuel. 1974. The Modern World System: Capitalist Agriculture and the Origins of the European World Economy in the Sixteenth Century. New York: Academic Press. 